\title{
PELATIHAN PRODUKSI GARAM RAKYAT DENGAN METODE TUNNEL BERSIRIP
}

\author{
Marita Ika Joesidawati ${ }^{*}$ dan Suwarsih \\ Program Studi IImu Kelautan Universias PGRI Ronggolawe Tuban \\ *) Korespondensi: maritajoes@gmail.com
}

Diterima 16 Juni 2019 / Disetujui 24 Juli 2019

\begin{abstract}
ABSTRAK
Produksi garam krosok di Tuban terletak di desa Pliwetan Kecamatan Palang Kabupaten Tuban, daerah ini merupakan daerah yang potensial untuk pengembangan dan perbaikan produksi garam. Luas wilayah produksi garam di desa pliwetan 31,4 $\mathrm{Ha}$, dan wilayah laut seluas $22.068 \mathrm{~km}^{2}$. Permasalahan yang dihadapi mitra antara lain: 1) Bahan baku yang masih mengandung kotoran dan lumpur sehingga mutu garam masih rendah. 2) Tehnologi Produksi yang konvensional 3) Faktor eksternal yang mempengaruhi produksi garam yaitu curah hujan yang tinggi yang dapat menurunkan hasil panen garam. Kegiatan ini bertujuan ini bertujuan untuk membantu mitra (pembuat garam rakyat) dalam mengatasi permasalahnya sehingga solusi penerapan TTG yang ditawarkan adalah pembuatan model tunnel bersirip untuk meningkatkan garam grosok produksi mitra tanpa terkendala cuaca yang tidak bersahabat. Sedangkan solusi lain yang ditawarkan antara lain: penyuluhan dan pengenalan produksi garam krosok dan pelatihan produksi garam dengan metode tunnel bersirip. Hasil menunjukkan pelatihan produksi garam dengan metode tunnel bersirip ini mampu memecahkan permasalahan yang dihadapi mitra terutama mereka tetap, namun tetap harus ada campur tangan pemerintah untuk memberi bantuan dalam pembuatan sirip metode tunnel bersirip
\end{abstract}

Kata Kunci: air tua, metode konvensional, curah hujan, banjir

\section{PENDAHULUAN}

Pemerintah Indonesia menargetkan adanya peningkatan produksi garam setiap tahunnya, hal ini dilakukan karena nilai impor garam yang selalu meningkat. Untuk mengatasi masalah impor garam tersebut diharapkan industri produksi garam rakyat meningkatkan produksinya. Seperti contoh produksi garam di lamongan pada tahun 2016 jika secara konvensional hanya menghasilkan 60-80 ton garam per hektar pada musim normal, kemudian dengan tehnologi rumah garam prisma dan geopolimer menghasilkan 120 125 ton per hektar atau bahkan 400 ton per hektar setahun di musim normal karena bisa terus produksi selama 1 tahun tanpa dipengaruhi musim (Assafri ,2017) Peningkatan produksi garam juga diharapkan meningkat di Kabupaten Tuban.

Desa Pliwetan sebagai salah satu wilayah yang memproduksi garam krosok di Kabupaten

Tuban dengan Luas wilayah produksi garam di desa Pliwetan 31,4 ha, dan wilayah laut seluas $22.068 \mathrm{~km}^{2}$, merupakan daerah yang potensial untuk pengembangan dan perbaikan produksi garam 
Kelompok produksi garam Pliwetan berpotensi untuk dikembangkan. Mitra pada pelatihan ini adalah Kelompok Penampan dengan produksi garam pertahunnya \pm 900 - 1000 ton/th dan luas lahan 8,79 ha dan Kelompok Galengan dengan produksi garam pertahunnya \pm 300 - 750 ton/th dan luas lahan 3.04 ha. Permasalahan umum yang dihadapi mitra antara lain : 1) produksi garam krosok yang masih konvensional dan bermutu rendah (mengandung lumpur dan kotoran). 2) Tingkat pendidikan sumber daya manusia yang masih rendah, 3) Garam yamg diproduksi banyak yang tidak diterima/dikembalikan pengepul karena mutunya rendah, 4) produksi garam menurun pada musim penghujan.

Masalah yang dihadapi mitra yang harus diselesai pada kegiatan ini adalah permasalahan dari bahan baku, proses produksi dan faktor eksternal yang mengganggu produksi. Bahan baku utama yang digunakan untuk membuat garam adalah air laut yang didiamkan (air tua). Kandungan garam pada air tua desa Pliwetan sebesar 22,9 be (Setiawan, 2018) dan sebaran kolam air tua ditunjukkan pada Gambar 1. Kandungan air tua ini baik sebagai produksi garam dan sebagai air pencuci (brine). Permasalahan yang dihadapi yaitu bahan baku yang masih mengandung kotoran dan lumpur sehingga mutu garam masih rendah.

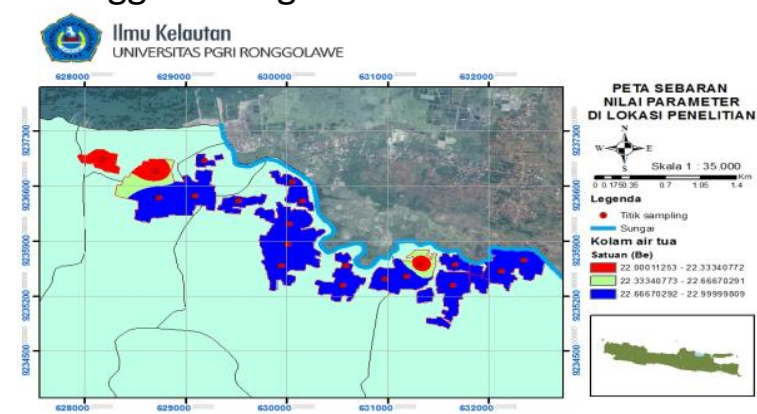

Gambar 1. Gambar pemetaan kolam air tua (Setiawan, 2018)
Teknologi pembuatan garam masih menggunakan metode konvensional seperti terlihat pada gambar berikut.

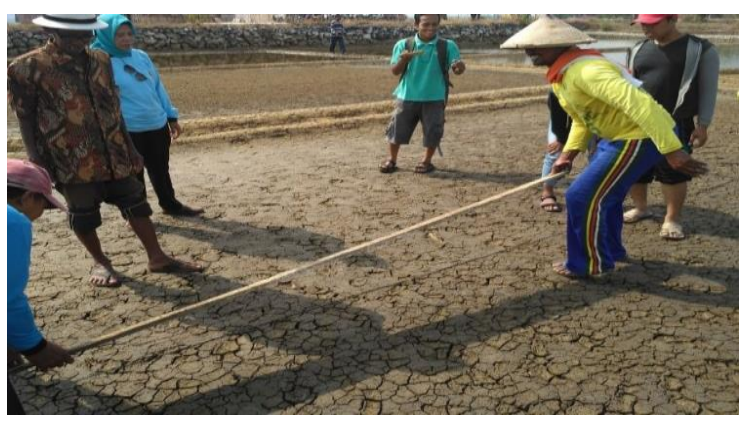

Gambar 2. Persiapan lahan

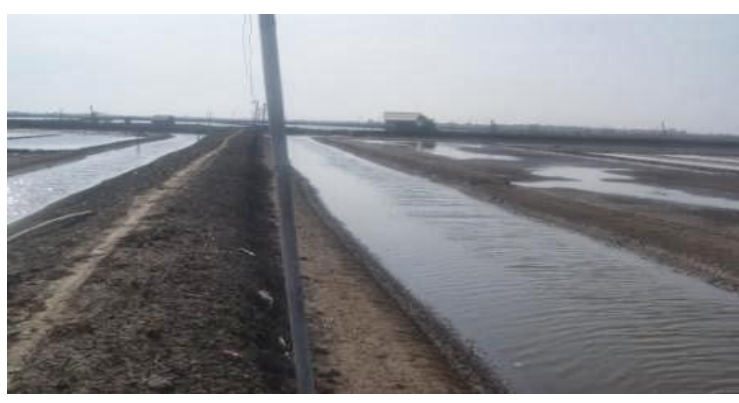

Gambar 3. Pengaliran air muda

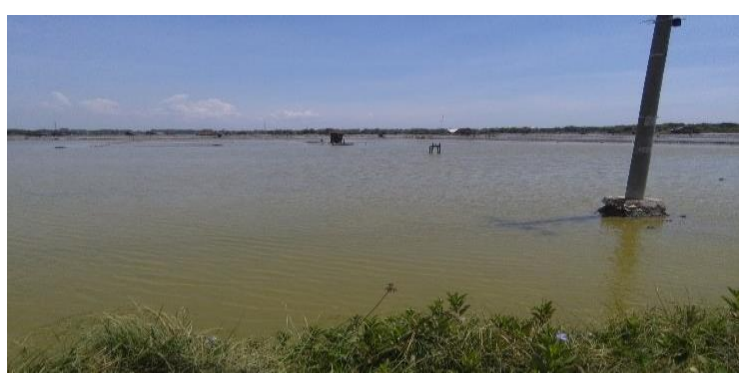

Gambar 4. Penampungan air muda

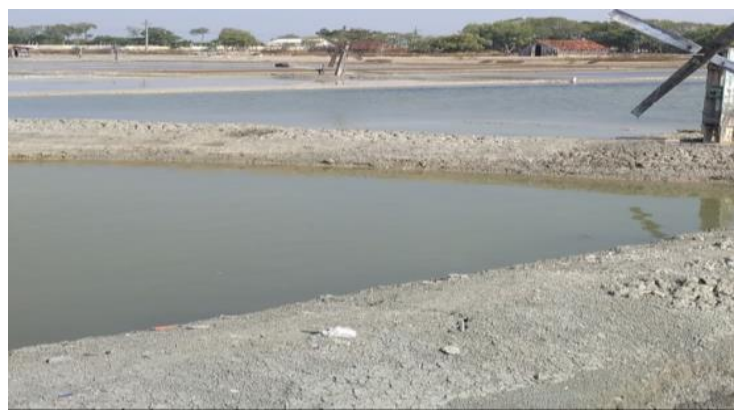

Gambar 5. Penampungan air tua 


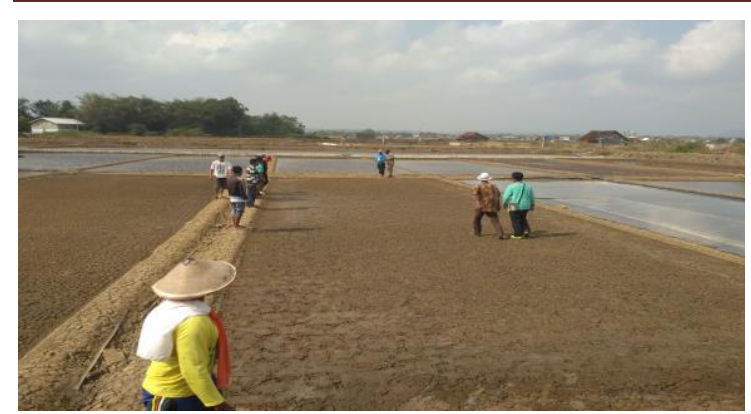

Gambar 6. Proses kristalisasi di meja kristal

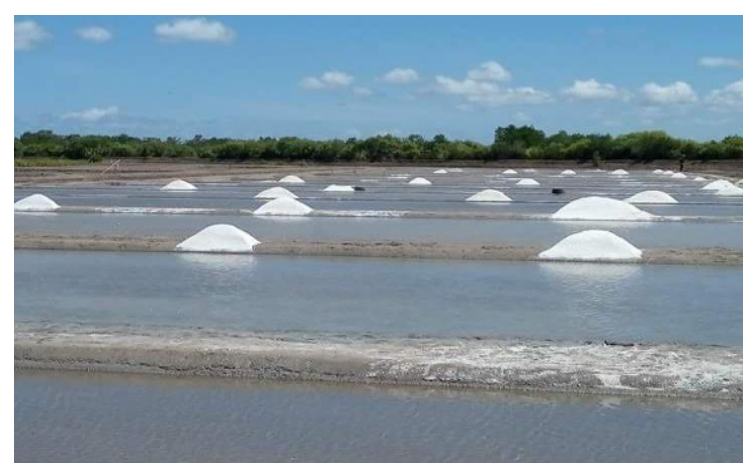

Gambar 7. Panen garam

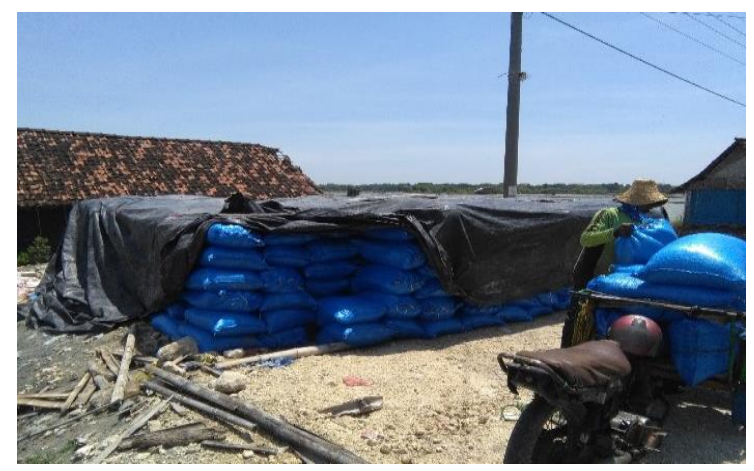

Gambar 8. Pengemasan

Berdasarkan gambar di atas dapat diketahui proses produksi garam masih menggunakan metode yang sangat sederhana. Proses penampungan air muda dan air tua tanpa poses filterisasi sehingga masih banyak kotoran. Hasil panen garam yang dihasilkan masih banyak mengandung kotoran dan lumpur sehingga banyak yang dikembalikan oleh perusahaan karena bermutu rendah. Dan hasil produksi garamnya masih rendah sekitar 60 ton per hektar.

Adapun faktor eksternal yang mempengaruhi produksi garam yaitu curah hujan yang tinggi yang dapat menurunkan hasil panen garam. Berdasarkan gambar di atas menunjukkan jumlah hari hujan dan intensitas hujan di Kecamatan palang sangat tinggi. Sehingga diperlukan suatu metode yang tidak memperhatikan musim dapat memproduksi garam dalam jumlah yang banyak.

\section{METODE KEGIATAN}

\section{Mitra Kegiatan}

1. Dua kelompok mitra produksi garam Desa Pliwetan Kecamatan Palang Kabupaten Tuban berperan aktif sebagai peserta dalam setiap kegiatan yang direncanakan dalam kegiatan pengabdian

2. Dinas Perikanan dan Peternakan Kabupaten Tuban, sebagai pihak intansi pemerintah yang bertugas memantau perkembangan kegiatan kelompok yang sudah mereka bentuk

\section{Tahapan Kegiatan}

Metode pelaksanaan pelatihan produksi garam menggunakan metode tunnel bersirip dengan prosedur kerja sebagai berikut.

1. Melakukan kerjasama dengan kepala desa Pliwetan untuk penentuan lokasi pemasangan metode tunnel bersirip

2. Melakukan pelatihan sekaligus pembuatan metode tunnel bersirip di lokasi yang sudah ditentukan oleh kepala desa

3. Pembuatan metode tunnel bersirip dibuat sebagai lokasi percontohan dan sekaligus dapat dimanfaatkan oleh kedua kelompok mitra

4. Melakukan pelatihan Inovasi filter bahan alam pada pada tahap awal pembuatan garam (air muda) sehingga diperoleh garam yang bersih

5. Melakukan pelatihan quality control produksi

6. Melakukan pelatihan produksi garam dengan teknologi tepat guna (metode 
tunnel bersirip) untuk memperoleh hasil maksimal

7. Monitoring, evaluasi dan pendampingan untuk keberlanjutan program

\section{HASIL DAN PEMBAHASAN}

\section{Metode Tunnel Bersirip}

Metode Tunnel bersirip pada bagian samping dari tunnel di buka dan diberi penyangga, maksud penggunaan sirip ini untuk mengurangi air jika terjadi banjir dan membantu pengontrolan penguapan. Adapun diskripsi TTG "Metode tunnel bersirip" seperti ditunjukkan pada Gambar 3 dan 4

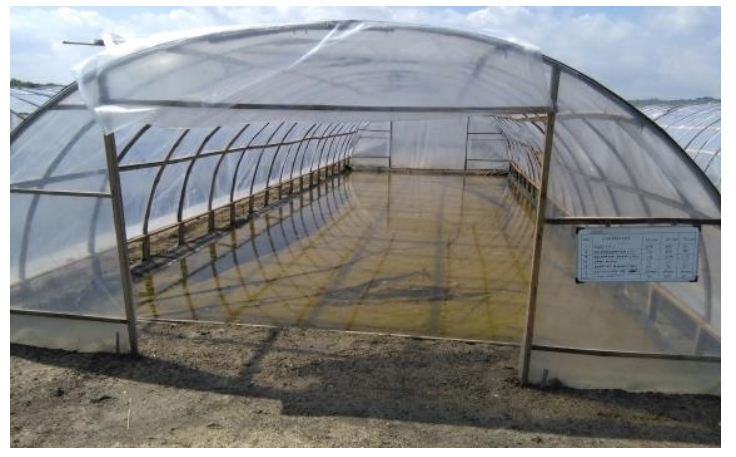

Gambar 3 Metode tunnel bersirip tampak depan

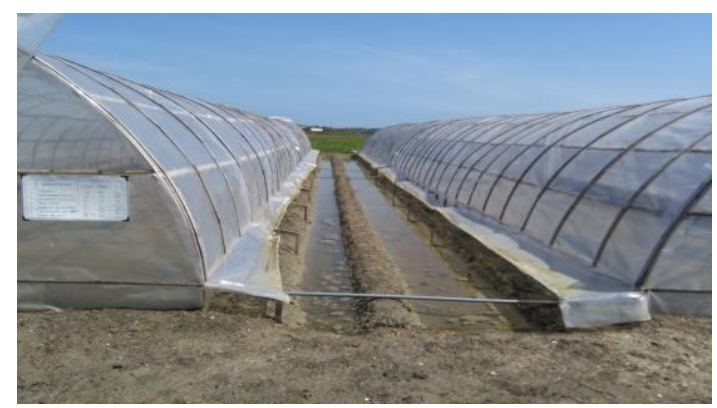

Gambar 4 Metode tunnel bersirip tampak depan dengan sisi samping kanan dan kiri yang dapat dibuka seperti sirip

Pelatihan produksi garam dengan menggunakan metode sirip bertunnel ini dapat merubah mindset petambak dalam memproduksi garam, bahwa banyak sekali metode yang dapat digunakan dalam meningkatkan produksi garam grosoknya, disamping itu mereka dapat memproduksi garam setiap waktu dan tidak hanya pada musim kemarau saja. Adanya model sirip pada bagian samping dari metode sirip dapat memberi solusi jika terjadi banjir (ROB), jika mereka memproduksi garam pada waktu musim penghujan

\section{KESIMPULAN DAN SARAN}

\section{A. Kesimpulan}

Pelatihan produksi garam dengan menggunakan metode tunnel bersirip ini merupakan salah satu solusi untuk memecahkan permasalahan yang dihadapi mitra, terutama tidak memproduksi garam grosok pada waktu musim penghujan dan terjadi ROB. Pengenalan metode tunnel bersirip ini merupakan ilmu baru bagi petambak garam dan dalam memproduksi garam dengan metode ini perlu ada monitoring dan evaluasi

\section{B. Saran}

Penggunaan metode tunnel bersirip dalam meningkatkan produksi garam rakyat di Kecamatan Palang perlu ditingkatnya dan perlu dikembangkan untuk kecamatan -kecamatan lain di Kabupaten Tuban, namun sangat diperlukan campur tangan pemerintah dalam pemberian subsidi untuk pembuatan metode tunnel bersirip

\section{UCAPAN TERIMA KASIH}

Ucapan terima kasih kepada Kepala Desa Pliwetan, Dinas Perikanan dan Peternakan Kabupaten Tuban dan Universitas PGRI Ronggolawe, Tuban yang mendukung kegiatan dan memberikan fasilitas, sehingga kegiatan dapat dikerjakan.

\section{DAFTAR PUSTAKA}

Assafri, Farikh, 2017. Kualitas Garam Hasil Produksi Rakyat Dengan Metode Prisma Rumah Kaca Di Desa Sedayu Lawas Kecamatan Brondong Kabupaten Lamongan, Jawa Timur. 
Sarjana thesis, Universitas

Brawijaya.

Setiawan, W., 2018 Studi Kesesuaian

Wilayah Pesisir Sebagai Lahan

Tambak Garam Di Kecamatan Palang Kabupaten Tuban. Prosiding Seminar

Nasional Hasil Penelitian dan Pengabdian kepada Masyarakat III: Peningkatan Kapasitas Hasil Penelitian dan Pengabdian kepada Masyarakat Menuju Revolusi Industri 4.0. Universitas PGRI Ronggolawe, pp 215-220.

BPS, 2017. Kecamatan Palang Dalam Angka 2017. Badan Pusat Statistik Kabupaten Tuban. Katalog BPS:

1102001.3523110 . 